\title{
DUKUNGAN SUAMI TERHADAP PEMBERIAN ASI EKSKLUSIF PADA IBU YANG MEMILIKI BAYI USIA 6-24 BULAN DI KOTA DENPASAR TAHUN 2017
}

\author{
Seshia Arma Dwi Permata*, I Ketut Tangking Widarsa, Ni Made Dian Kurniasari \\ Program Studi Kesehatan Masyarakat Fak. Kedokteran Universitas Udayana \\ *email: seshiaarma27@gmail.com
}

\begin{abstract}
ABSTRAK
ASI eksklusif merupakan pemberian Air Susu Ibu (ASI) saja selama minimal enam bulan tanpa memberikan makanan pendamping ASI (MP-ASI) lainnya. Pemerintah Indonesia telah menggalakkan program pemberian ASI Eksklusif sejak tahun 1990 dengan Standar Pelayanan Minimum (SPM) Nasional Cakupan ASI Eksklusif sebesar 80\% (Depkes, 2015). Namun, cakupan ASI eksklusif di Indonesia masih di bawah target yang telah ditetapkan. Bahkan cakupan ASI eksklusif di Denpasar tahun 2016 menurun tajam hingga mencapai 46,1\% saja. Tujuan dari penelitian ini adalah untuk menganalisis dukungan suami terhadap pemberian ASI eksklusif pada ibu yang memiliki bayi usia 6-24 bulan di Kota Denpasar Tahun 2017. Penelitian ini merupakan penelitian analitik kuantitatif menggunakan pendekatan cross-sectional, yang dilakukan di Posyandu Wilayah Kerja Puskesmas I Denpasar Barat dan Puskesmas II Denpasar Utara, jumlah sampel sebanyak 96 orang dan menggunakan teknik multistage random sampling melalui pembagian kuesioner. Hasil penelitian menunjukkan lebih dari setengah responden mendapatkan dukungan yang baik dari suami, baik itu dukungan dukungan informasional (66,7\%), dukungan penilaian (63,5\%), dukungan instrumental (62,5\%), dan dukungan emosional (61,5\%). Disimpulkan bahwa dukungan suami memiliki pengaruh sebesar $80,2 \%$ dimana terdapat dua variabel yang berpengaruh positif terhadap pemberian ASI eksklusif yaitu dukungan informasional (OR: 124,15; 95\% CI: 10,50 - 1467,23) serta dukungan instrumental (OR: 15,75; 95\% CI: 2,40 - 103,31), yang masih dalam kategori kurang adalah suami jarang menyediakan peralatan ASI perah dan jarang membimbing ibu cara memerah dan memberikan ASI perah kepada bayi. Disarankan untuk meningkatkan peran serta suami dengan cara memberikan edukasi sejak dini oleh petugas kesehatan khususnya bidan terkait ASI eksklusif sehingga suami dapat memberikan dukungan yang positif kepada ibu.
\end{abstract}

Kata kunci : Dukungan Suami, ASI eksklusif, bayi usia 6-24

\begin{abstract}
Exclusive breastfeeding is the provision of breast milk only for a minimum of six months without any complementary food. Indonesian government has been promoting exclusive breastfeeding program since 1990 with the National Minimum Service Standards (SPM) of exclusive breastfeeding coverage of $80 \%$. However, exclusive breastfeeding coverage in Indonesia is still below the target. Exclusive breastfeeding coverage in Denpasar in year 2016 dropped sharply to $46.1 \%$. The purpose of this study was to analyze the husband's support for exclusive breastfeeding for mothers who have babies aged 6 to 24 months old in Denpasar. This research is a quantitative analytic study using a cross-sectional approach, which was conducted at the Integrated Health Posts (Posyandu) in the area of Public Health Center (Puskesmas) I West Denpasar and Puskesmas II North Denpasar. Survey questionnaire was conducted to 96 samples selected using multistage random sampling technique. The results showed that more than a half of respondents received good support from their husbands, in the forms of informational support (66.7\%), assessment support (63.5\%), instrumental support $(62.5 \%)$, and emotional support $(61,5 \%)$. It was concluded that husband's support had an influence of $80.2 \%$ where there were two variables that had a positive effect on exclusive breastfeeding, namely informational support (OR: 124.15; 95\% CI: 10.50 1467.23) and instrumental support (OR: 15.75; 95\% CI: 2.40 - 103.31). Husband's support was still lacking on the provision of equipment to express breast milk, guidance on how to express the breastmilk, and on how to give the milk to the baby. Health workers, especially midwives, should provide early education to husband in order to improve husband's participation and support to breastfeeding mothers.
\end{abstract}

Keywords : Husband support, exclusive breastfeeding, 6 to 24 months old babies

\section{PENDAHULUAN}

ASI eksklusif merupakan

pemberian Air Susu Ibu (ASI) saja selama minimal enam bulan tanpa memberikan makanan pendamping ASI (MP-ASI) lainnya. ASI sangat kaya akan manfaat karena mengandung growth factor yang 
berguna bagi pertumbuhan bayi dan mengandung antibodi yang akan melindungi bayi dari berbagai penyakit. Pemberian ASI sangat penting mengingat ASI adalah satu-satunya makanan dan minuman yang terbaik untuk bayi dalam masa enam bulan pertama kehidupannya (Proverawati dan Rahmawati, 2010). Pemerintah Indonesia telah menggalakkan program pemberian ASI Eksklusif sejak tahun 1990 yang dikenal dengan Gerakan Nasional Peningkatan Pemberian Air Susu Ibu (PP-ASI) dengan Standar Pelayanan Minimum (SPM) Nasional Cakupan ASI Eksklusif sebesar 80\% (Depkes, 2015).

Cakupan ASI eksklusif di Indonesia masih di bawah target yang telah ditetapkan. Data dari Dinas Kesehatan Kota Denpasar menunjukkan bahwa cakupan ASI Eksklusif di Kota Denpasar mengalami penurunan yang cukup signifikan yaitu dari $75,3 \%$ pada tahun 2015 menjadi hanya sebesar 46,1\% saja pada tahun 2016.

Ada banyak faktor yang dapat mempengaruhi kegagalan ibu untuk memberikan ASI secara eksklusif kepada bayinya, salah satunya adalah kurangnya dukungan dari suami. Penelitian yang dilakukan oleh Hargi

menyimpulkan bahwa dukungan suami memiliki hubungan yang signifikan terhadap sikap ibu dalam pemberian ASI eksklusif. Dukungan tersebut dibagi menjadi 4 yaitu dukungan informasional, dukungan penilaian, dukungan instrumental dan dukungan emosional. Studi pendahuluan telah dilakukan kepada 15 orang ibu menyusui yang berkunjung ke Bidan Praktek Mandiri (BPM) Ni Wayan Sukanadi, S.ST dengan metode wawancara untuk mengetahui peran suami dalam keberhasilan pemberian ASI eksklusif, 11 orang diantaranya (73,3\%) mengatakan mendapatkan dukungan dari suami selama memberikan ASI kepada bayinya. Sedangkan 4 orang lainnya (26,7\%) mengatakan bahwa tidak mendapat dukungan dari suami saat memberikan ASI kepada bayinya. Berdasarkan hal tersebut, maka dilakukan sebuah penelitian untuk mengetahui lebih lanjut peran suami dalam keberhasilan ASI eksklusif.

\section{METODE}

Desain penelitian ini adalah penelitian analitik kuantitatif dengan rancangan cross-sectional. Penelitian ini dilaksanakan di posyandu wilayah kerja Puskesmas I Denpasar Barat dan posyandu wilayah kerja Puskesmas II Denpasar Utara dengan sampel ibu yang memiliki bayi usia 6-24 bulan sejumlah 96 orang. Pemilihan lokasi dilakukan dengan teknik multistage random sampling kemudian pemilihan sampel individu dilakukan secara accidental sampling. Data dukungan suami dan pemberian ASI eksklusif dikumpulkan dengan menggunakan kuesioner kemudian dianalisis secara univariat, bivariat, dan multivariat dengan menggunakan bantuan software computer untuk menganalisis data. 


\section{HASIL}

\section{Karakteristik Responden}

Tabel 1. Karakteristik Responden Dukungan Suami Terhadap Pemberian ASI Eksklusif

\begin{tabular}{|c|c|c|c|}
\hline Karakteristik Responden & $\begin{array}{c}\text { Tidak ASI } \\
\text { n (\%) }\end{array}$ & $\begin{array}{c}\text { ASI } \\
\text { n (\%) }\end{array}$ & $\begin{array}{l}\text { Total } \\
\text { n (\%) }\end{array}$ \\
\hline \multicolumn{4}{|l|}{ Kelompok Umur } \\
\hline$<20$ thn & $0(0,0)$ & $0(0,0)$ & $0(0,0)$ \\
\hline $20-35$ thn & $23(74,2)$ & $53(81,5)$ & $76(79,2)$ \\
\hline$>35$ thn & $8(25,8)$ & $12(18,5)$ & $20(20,8)$ \\
\hline \multicolumn{4}{|l|}{ Jumlah Anak } \\
\hline Primipara & $17(54,8)$ & $46(70,8)$ & $63(65,6)$ \\
\hline Multipara & $14(45,2)$ & $19(29,2)$ & $33(34,4)$ \\
\hline \multicolumn{4}{|l|}{ Umur Anak Terkecil } \\
\hline 6-12 bulan & $19(61,3)$ & $41(63,1)$ & $60(62,5)$ \\
\hline$>12$ bulan & $12(38,7)$ & $24(36,9)$ & $36(37,5)$ \\
\hline \multicolumn{4}{|l|}{ Pendidikan Suami } \\
\hline SD-SMP & $5(16,1)$ & $7(10,8)$ & $12(12,5)$ \\
\hline SMA-PT & $26(83,9)$ & $58(89,2)$ & $84(87,5)$ \\
\hline \multicolumn{4}{|l|}{ Pendidikan Istri } \\
\hline SD-SMP & $9(29,0)$ & $9(13,8)$ & $18(18,7)$ \\
\hline SMA-PT & $22(71,0)$ & $56(86,2)$ & $78(81,3)$ \\
\hline \multicolumn{4}{|l|}{ Pekerjaan Suami } \\
\hline Bekerja & $31(100)$ & $65(100)$ & $96(100)$ \\
\hline Tidak & $0(0,0)$ & $0(0,0)$ & $0(0,0)$ \\
\hline \multicolumn{4}{|l|}{ Pekerjaan Istri } \\
\hline Bekerja & $18(58,1)$ & $47(72,3)$ & $65(67,7)$ \\
\hline Tidak & $13(41,9)$ & $18(27,7)$ & $31(32,3)$ \\
\hline \multicolumn{4}{|l|}{ Penghasilan } \\
\hline$\geq \operatorname{Rp} 3.000 .000,-$ & $17(54,8)$ & $43(66,2)$ & $60(62,5)$ \\
\hline$<\operatorname{Rp} 3.000 .000,-$ & $14(45,2)$ & $22(33,8)$ & $36(37,5)$ \\
\hline
\end{tabular}

Hasil dari 96 responden menunjukkan bahwa ibu yang memberikan ASI eksklusif kepada bayinya sebesar $67,7 \%$. Berdasarkan tabel 1, dapat diketahui responden terbanyak berusia 20-35 tahun $(79,2 \%)$, baru memiliki satu anak $(65,6 \%)$ dan memiliki anak usia 6-12 bulan (62,5\%). Hampir seluruh suami responden berpendidikan SMA sampai Perguruan
Tinggi $(87,5 \%)$, begitu juga dengan istri berpendidikan SMA sampai Perguruan Tinggi $(81,3 \%)$, seluruh suami bekerja sedangkan lebih dari setengah istri bekerja $(67,7 \%)$ dan memiliki rata-rata penghasilan lebih dari Rp 3.000.000,- per bulan $(62,5 \%)$. 
Dukungan Suami Terhadap Pemberian ASI Eksklusif

Tabel 2. Dukungan Suami Terhadap Pemberian ASI Eksklusif

\begin{tabular}{cccc}
\hline Karakteristik Responden & $\begin{array}{c}\text { Tidak ASI } \\
\text { n (\%) }\end{array}$ & $\begin{array}{c}\text { ASI } \\
\mathbf{n ~ ( \% )}\end{array}$ & $\begin{array}{c}\text { Total } \\
\mathbf{n}(\mathbf{\%})\end{array}$ \\
\hline $\begin{array}{c}\text { Dukungan Informasional } \\
\text { Baik }\end{array}$ & $3(3,1)$ & $61(63,5)$ & $64(66,7)$ \\
Kurang & $4(4,2)$ & $28(29,1)$ & $32(33,3)$ \\
Dukungan Penilaian & & & \\
Baik & $6(6,2)$ & $55(57,3)$ & $61(63,5)$ \\
Kurang & $25(26)$ & $10(10,4)$ & $35(36,5)$ \\
Dukungan Instrumental & & & $60(62,5)$ \\
Baik & $4(4,2)$ & $56(58,3)$ & $36(37,5)$ \\
Kurang & $27(28,1)$ & $9(9,3)$ & $59(61,5)$ \\
Dukungan Emosional & & $52(54,2)$ & $37(38,5)$ \\
Baik & $7(7,3)$ & $13(13,5)$ & \\
Cukup & $24(25)$ & $C 1: 29,84$ & yang
\end{tabular}

Berdasarkan Tabel 2, dapat diketahui bahwa lebih dari setengah responden mendapatkan dukungan informasional yang baik dari suami (66,7\%), mendapatkan dukungan penilaian yang baik dari suami (63,5\%), mendapatkan dukungan instrumental yang baik dari suami (62,5\%), dan mendapatkan dukungan emosional yang baik dari suami $(61,5 \%)$.

\section{Pengaruh Dukungan Suami Terhadap Pemberian ASI Eksklusif}

Berdasarkan analisis bivariat, dapat diketahui bahwa terdapat hubungan antara dukungan informasional, dukungan penilaian, dukungan instrumental, dan dukungan emosional terhadap pemberian ASI eksklusif. Ibu yang mendapatkan dukungan informasional dari suami lebih memungkinkan memberikan ASI eksklusif 142 kali lipat daripada yang tidak mendapat dukungan (OR: 142,33;

95\% CI: 29,84 - 678,95). Ibu yang
mendapatkan dukungan penilaian dari suami lebih memungkinkan memberikan ASI eksklusif 22 kali lipat daripada yang tidak mendapat dukungan (OR: 22,92; 95\% CI: 7,50 - 70,03). Ibu yang mendapatkan dukungan instrumental dari suami lebih memungkinkan memberikan ASI eksklusif 42 kali lipat daripada yang tidak mendapat dukungan (OR: 42,00; 95\% CI: 11,86 - 148,68). Dan ibu yang mendapatkan dukungan emosional dari suami lebih memungkinkan memberikan ASI eksklusif 13 kali lipat daripada yang tidak mendapat dukungan (OR: 13,71; 95\% CI: 4,86 - 38,74). Berdasarkan analisis multivariat dapat diketahui, terdapat dua variabel yang berpengaruh terhadap pemberian ASI eksklusif yaitu dukungan informasional (OR: 124,15; 95\% CI: 10,50 $1467,23)$ serta dukungan instrumental (OR: 15,75; 95\% CI: 2,40 - 103,31). 


\section{DISKUSI}

\section{Hubungan Dukungan Suami Terhadap} Pemberian ASI Eksklusif

Hasil dari uji analisis bivariat membuktikan bahwa dukungan suami dari keempat komponen tersebut berhubungan terhadap pemberian ASI eksklusif. Hasil yang sama juga diperoleh dari penelitian yang dilakukan oleh Priscilla, dkk (2011) di Kota Padang yang menyebutkan bahwa ada hubungan yang bermakna antara keempat dukungan suami baik dukungan informasional, dukungan penilaian, dukungan instrumental dan dukungan emosional.
Vol. 5 No. $1: 27$ - 32

Teori dari Budiasih (2008) menyebutkan bahwa perhatian dan rasa nyaman yang diberikan oleh suami akan meningkatkan pikiran positif ibu, hal ini dapat meningkatkan refleks prolaktin dan refleks let down sehingga produksi ASI menjadi lebih lancar. Dengan menyediakan makanan yang bergizi, memijat ibu, dan menemani ibu untuk berkonsultasi ke fasilitas kesehatan akan meningkatkan stamina ibu menjadi lebih sehat dan kuat agar semangat menyusui bayinya, sehingga produksi ASI akan lancar dan memungkinkan untuk memberikan ASI secara eksklusif. terhadap pemberian ASI eksklusif.

Tabel 3. Pengaruh Dukungan Suami Terhadap Pemberian ASI Eksklusif

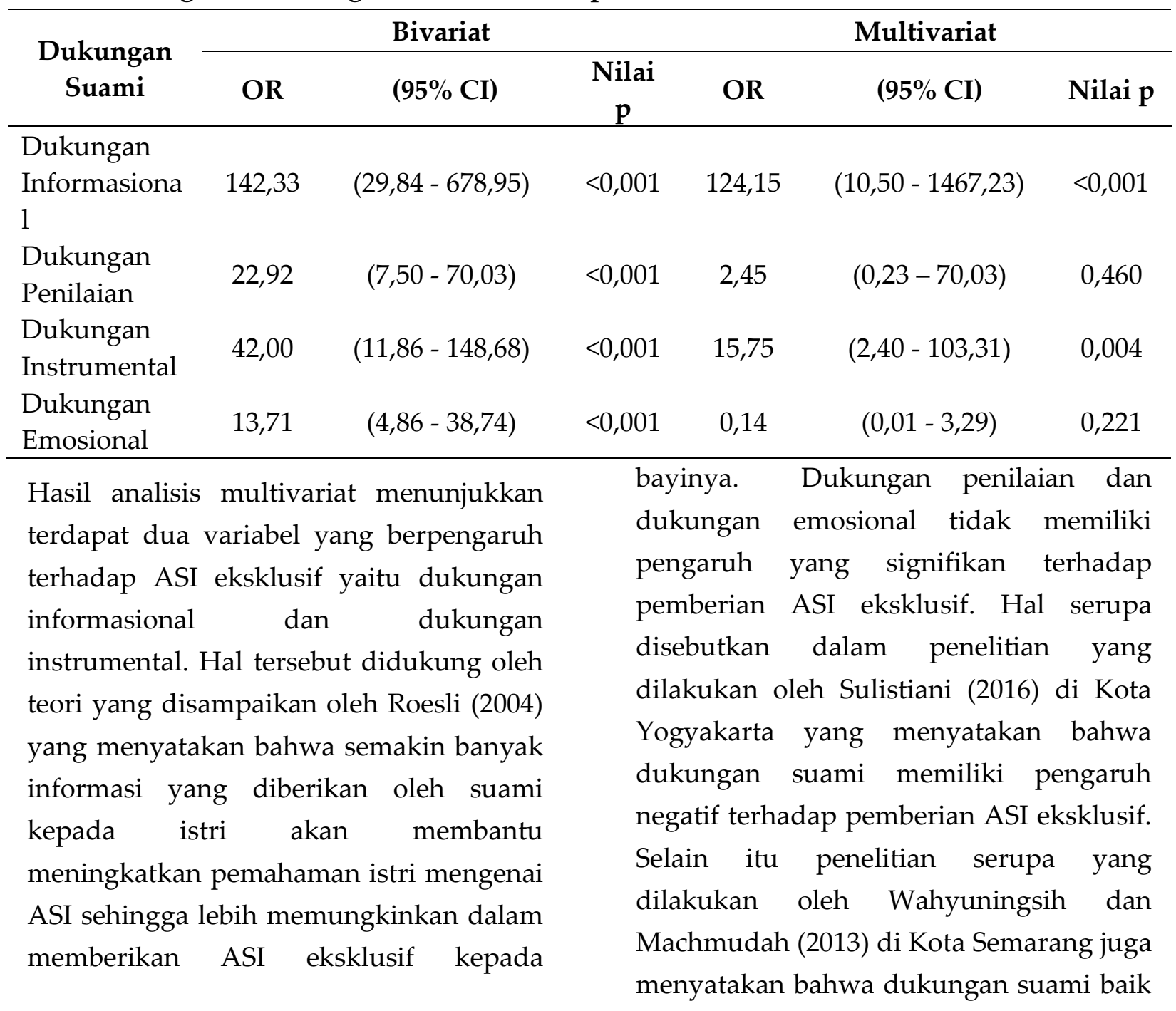


itu dukungan informasional, dukungan penilaian, dukungan instrumental dan dukungan emosional tidak memiliki pengaruh terhadap keberhasilan ASI eksklusif.

Dukungan suami merupakan salah satu faktor penting yang dapat mempengaruhi keberhasilan ASI eksklusif. Dengan diberikannya edukasi mengenai ASI eksklusif sejak dini khususnya kepada suami, diharapkan hal tersebut akan menambah pengetahuan dan menciptakan motivasi yang kuat untuk dapat memberikan ASI eksklusif kepada bayinya sehingga cakupan ASI dapat meningkat sesuai dengan standar pelayanan minimum (SPM) yang diharapkan.

\section{SIMPULAN}

Lebih dari setengah responden mendapatkan dukungan yang baik dari suami, baik itu dari dukungan informasional (66,7\%), dukungan penilaian $(63,5 \%)$, dukungan instrumental $(62,5 \%)$ dan dukungan emosional (61,5\%). Dukungan suami memiliki pengaruh terhadap pemberian ASI eksklusif sebesar $80,2 \%$ dimana hanya dukungan informasional dan dukungan instrumental yang memiliki pengaruh positif terhadap pemberian ASI eksklusif, sedangkan dua variabel sisanya yaitu dukungan penilaian dan dukungan emosional tidak memiliki pengaruh terhadap pemberian ASI eksklusif.

Diharapkan peran serta petugas kesehatan khususnya bidan untuk memberikan edukasi sejak dini kepada suami sehingga dapat meningkatkan pengetahuan suami tentang ASI eksklusif serta dapat menciptakan dukungan yang positif untuk mendukung ibu memberikan ASI saja kepada bayinya selama enam bulan penuh dan cakupan ASI eksklusif dapat memenuhi standar yang telah ditetapkan.

\section{DAFTAR PUSTAKA}

Budiasih, Sri. 2008. Handbook Ilmu Menyusui. Bandung: Karya Kita

Dinas Kesehatan Kota Denpasar. 2016. Profil Kesehatan Kota Denpasar Tahun 2015. Kota Denpasar

Dinas Kesehatan Provinsi Bali. 2016. Profil Kesehatan Provinsi Bali Tahun 2015. Provinsi Bali

Hargi, JP. 2013. Hubungan Dukungan Suami dengan Sikap Ibu dalam Pemberian ASI Eksklusif. [Skripsi Ilmiah]. Jember: Universitas Jember

Priscilla, dkk. 2014. Dukungan Suami Terhadap Pemberian ASI Eksklusif di Wilayah Kerja Puskesmas Lubuk Kilangan Kota Padang. [Skripsi Ilmiah]. Padang: Universitas Andalas

Proverawati dan Rahmawati. 2010. Kapita Selekta: ASI dan Menyusui. Yogyakarta: Nuha Medika

Roesli. 2004. ASI dan Manfaatnya. Jakarta:

Trubus Agriwidya

Sulistiani, Retno.2016. Pengaruh Dukungan Suami Terhadap Pemberian ASI Eksklusif di Wilayah Kerja Puskesmas Pakualaman Kota Yogyakarta. [Skripsi Ilmiah] Available: http://digilib.uns.ac.id [1 Juli 2017 pukul 10.00 wita] 